\title{
Effects of chromium on seed germination, root elongation and coleoptile growth in six pulses
}

\author{
*R. Jun; T. Ling; Z. Guanghua
}

School of Environmental and Municipal Engineering and Institute of Environmental Ecology, Lanzhou Jiaotong University, Lanzhou, Lanzhou University, Lanzhou 730070, Gansu, P. R. China

Received 14 November 2008; $\quad$ revised 16 April 2009; accepted 5 August 2009; $\quad$ available online 1 September 2009

\begin{abstract}
The ecotoxicological effects of $\mathrm{Cr}^{2+}$ on germination and early seedling growth of six pulses were investigated. Seeds of these plants were exposed to seven different concentrations of $\mathrm{Cr}(0-3.2 \mathrm{mM})$. The results indicated that root elongation and coleoptile growth of six pulse plants were more sensitive than seed germination for measurement of the toxic of $\mathrm{Cr}^{2+}$ pollutions. Different species show different levels of tolerance to $\mathrm{Cr}^{2+}$ pollution. Lablab purpureus and Glycine max are the most sensitive to $\mathrm{Cr}^{2+}$, their germination percentage, root and coleoptile length were significantly lower than other tested species, by contrast, Lathyrus odoratus and Dumasia villosa are the most resist species, their germination and seedling growth almost were not influenced by $\mathrm{Cr}^{2+}$ pollution significantly comparing the control. There were significantly negatively correlations between seedling growth and increasing concentration of $\mathrm{Cr}^{2+}$ for Glycine max, Vigna radiate and Lablab purpureus. The significantly negative correlations between germination and increasing concentration of $\mathrm{Cr}^{2+}$ were shown for Glycine max, Vigna radiate and V. angularis.
\end{abstract}

Keywords: Chromium; Coleoptile growth; Germination; Pulse; Root elongation

\section{INTRODUCTION}

Chromium is important for metallurgical industry. Its salts are used in many industrial processes and product such as, steel production, electroplating, leather tanning, metal finishing, metal corrosion inhibition, textile paints and pigment manufacture, catalysts application, drilling muds, fungicides and nuclear weapons production and hence are present in effluents of those industries and in municipal sewage (Wong et al., 2001; Zayed and Terry, 2003; Nath et al., 2005; Babel and Opiso, 2007; Venkateswaran et al., 2007). Chromium is the second most common heavy-metal contaminant in groundwater, soil and sediments (Wong et al., 2001; Srivastava and Thakur, 2006; Shrestha et al., 2007; Kar et al., 2008; Ogundiran and Afolabi, 2008) and although in higher concentration, chromium ions which are more or less insoluble in the soils, can create potentially toxic environments for plant growth (Hasnain and Sabri, 1997; Wong et al., 2001; Srivastava and Thakur, 2006). Chromium phytotoxicity has been considered to be inhibitory for plant growth, its presence in excess amount within the plant can cause stunted shoot growing, root developing poorly (Bishnoi et al., 1993; Citterio et al., 2003; Dube et al., 2003; Faisal and * *Corresponding Author Email: renjun@mail.lzjtu.cn Tel.: +86931 4938 030; Fax: +86931 7667661
Hasnaim, 2005; Gbaruko and Friday, 2007). Chromium toxicity in plants also leads to leaves chlorosis, tissue necrosis, decreases enzyme activity, causes membrane damage, diminished photosynthesis and changing of chloroplast (Jain et al., 2000; Parmar et al., 2002; Du et al., 2003; Dube et al., 2003; Zayed and Terry, 2003; Scoccianti et al., 2006). The toxicity of chromium and chromium-content in plants, however, is species specific. Much research has been conducted to determine the toxic effects of chromium on different plant species (Hasnain and Sabri, 1997; Jain et al., 2000; Ren and Gao, 2000; Peralta et al., 2001; Zeid, 2001; Manjappa et al., 2002; Dube et al., 2003; Zhou and Li, 2003; 2004; Faisal and Hasnaim, 2005; Gardea-Torresdey et al., 2005; Jamal et al., 2006; Li and Yang, 2006; Karbassi et al., 2008). However, little information is available on the ecological effects and toxicity of chromium on 6 pulse plants (Leguminosae) which are widely cultivated around the world as crop species. These pulse plants can uptake heavy metal from polluted soil (Bishnoi et al., 1993). The heavy metals accumulated by pulse plants can threat health of human by entering the food chain as food or fodder. The present study was undertaken with a view to find out the toxic effect of chromium on seed germination, root 
elongation and coleoptile growth of six pulse crops. With the specific aim of determining: 1) What degree chromium inhibits the six pulse crops' seed germination and seedling growth? 2) Which pulses are most sensitive to chromium? This study was carried out on June of 2008 in Institute of Environmental Ecology, Lanzhou Jiaotong University.

\section{MATERIALS AND METHODS}

The effects of several doses of $\mathrm{K}_{2} \mathrm{Cr}_{2} \mathrm{O}_{7}(0,0.1,0.2$, $0.4,0.8,1.6$ and $3.2 \mathrm{mM}$ ) were studied on six pulse crops. Seeds of soybean (Glycine max (Linn.)), mung bean (Vigna radiata (Linn.) Wilczek.), hyacinth (Lablab purpureus (Linn.) Sweet), sweet pea (Lathyrus odoratus Linn.), adzuki bean (Vigna angularis (Willd.) Ohwietohashi.) and black bean (Dumasia villosa DC.) were offered by Gansu Academy of Agricultural Sciences of China. Seeds were surface sterilized in $0.5 \%$ sodium hypochlorite solution for $20 \mathrm{~min}$ and washed thoroughly with distilled water. The seeds were germinated in Petri dishes (diameter $=150 \mathrm{~mm}$ ) with double layer of filter paper soaked in distilled water (control) and 0.1-3.2 $\mathrm{mM} \mathrm{CrCl}$, solutions. The seeds were set under a photoperiod of $12 \mathrm{~h}$ and $30 \pm 1 / 25 \pm 1^{\circ} \mathrm{C}$ day/night temperature. The seedling was harvested after $96 \mathrm{~h}$ and the germination rate was recorded. A 1-mm radical emergence from seeds was considered seed germination. The root and coleoptile length of 10 germinated seeds were measured at $96 \mathrm{~h}$ under each treatment. Data are the results from six separate analyses with 50 seeds in each Petri. Statistical analysis was performed based on STATISTICA (Statsoft, 1993). The data were analyzed through oneway analysis of variance (ANOVA) to determine the effect of treatments and least significant difference (LSD) test were performed to determine the statistical significance of the differences between means of treatments.

\section{RESULTS AND DISCUSSION}

\section{Germination under chromium stress}

The germination of pulse seeds occurred at all chromium treatments from $0.0 \mathrm{mM}$ to $3.2 \mathrm{mM}$ for each species (Fig. 1). A two-way ANOVA showed that seed germination was significantly affected by different species $\left(F_{5}=4.6022, P<0.001\right)$ and chromium treatment $\left(F_{6}=2.9076, P<0.001\right)$ and the absent of a significant interaction demonstrates that the response of all species to chromium concentration was similar, although percentage of germination varies among the species (Table 1).

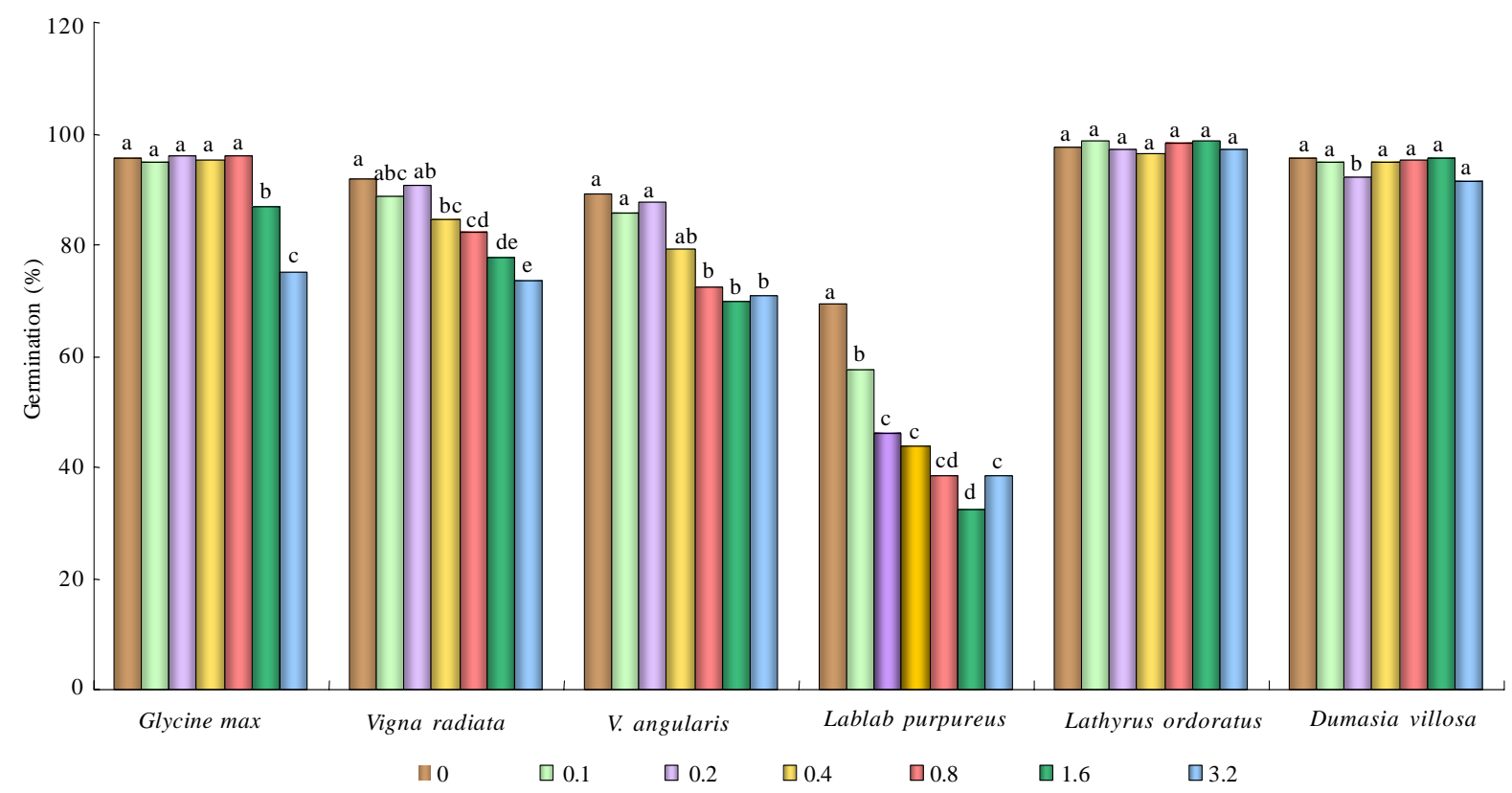

Fig. 1: Germination percentage of six test species under seven different chromium pollution treatments. Values with the same superscript letters are not significantly different among treatments at $\mathrm{p}<0.01$ according to Duncan's multiple comparison tests 
Table 1: The analysis of variance for the effects of different species, chromium treatments and their interaction on seed germination (\%), coleoptile and root growth for six pulse species

\begin{tabular}{|c|c|c|c|c|}
\hline Traits & Source of variation & $\mathrm{df}$ & $F$-value & $P$ \\
\hline \multirow{2}{*}{ germination } & chromium treatment & 6 & 2.9076 & $<0.001$ \\
\hline & chromium treatment $\times$ species & 24 & 1.3071 & 0.1152 \\
\hline \multirow[t]{3}{*}{ coleoptile growth } & chromium treatment & 6 & 2.2858 & 0.0263 \\
\hline & species & 5 & 2.9165 & $<0.001$ \\
\hline & chromium treatment $\times$ species & 24 & 0.9665 & 0.5507 \\
\hline \multirow{2}{*}{ root elongation } & species & 5 & 2.0134 & 0.0074 \\
\hline & chromium treatment $\times$ species & 24 & 1.0714 & 0.3738 \\
\hline
\end{tabular}

The germination was significantly different among chromium treatment and control in 5 pulse species (one-way ANOVA: $F_{6,35}=108.82, p<0.001$ for Glycine $\max ; F_{6,35}=9.62, p<0.001$ for Vigna ratiata; $F_{6,35}=$ $6.20, p<0.01$ for $V$. angularis; $F_{6,35}=18.98, p<0.001$ for Lablab purpureus; $F_{6,35}=5.78, p<0.01$ for Dumasia villosa). Only in the case of Lathyrus odoratus, its germination was not significantly effected by chromium treatment $\left(F_{6,35}=0.60, p=0.73\right)$ and it performed higher germination percentage and stronger tolerance to chromium. Compared with the control and lower concentration chromium treatments (0.1 and $0.2 \mathrm{mM}$ ), higher concentration chromium treatments ( 1.6 and $3.2 \mathrm{mM})$ significantly $(p<0.001)$ inhabited germination for Glycine max, Vigna ratiata, V. angularis and Lablab purpureus (Fig. 1).

The germination was significantly different $(p<0.001)$ among species at six kinds of chromium treatments and one control (Table 2). At all chromium treatments and control, the germination percentages of Lablab purpureus was significantly lower than other 5 species $(p<0.001)$. At control and $0.1 \mathrm{mM}$ chromium treatment, the germination percentage of $V$. angularis was significantly higher than Lablab purpureus and lower than other 4 species $(p<0.001)$. At control and $0.2,0.4$ and $0.8 \mathrm{mM}$ chromium treatment, the germination percentages of Glycine max, Lathyrus odoatus and Dumasia villosa did not performed significantly difference, and were significantly higher than Vigna ratiata, $V$. angularis and Lablab purpureus ( $p<0.001$ ), there was not significant difference in germination percentages between Vigna ratiata and V. angularis. At higher concentration chromium treatment (1.6 and $3.2 \mathrm{mM}$ ), the germination percentages of Lathyrus odoatus and
Dumasia villosa did not performed significantly difference and were significantly higher than other 4 species $(p<0.001)$ and there was not significant difference in germination percentages between Glycine max and Vigna ratiata (Table 2). There was a significant negative correlation between the mean percent germination and chromium concentration for Glycine max, Vigna ratiata and V. angularis $(p<0.001)$ (Table 3).

\section{Coleoptile growth under chromium stress}

A two-way ANOVA showed that coleoptile growth was significantly affected by different species $\left(F_{5}=2.9165, P<0.001\right)$ and chromium treatment $\left(F_{6}=\right.$ 2.2858, $P=0.0263)$, but not by the interaction between species and chromium treatment (Table 1). The coleoptile length was significantly different among chromium treatments in 3 pulse species (one-way ANOVA: $F_{6,35}=5.37, p<0.001$ for Glycine max; $F_{6,35}=$ 13.68, $p<0.001$ for Vigna ratiata; $F_{6,35}=14.68$, $p<0.001$ for Lablab purpureus). For the other 3 pulse species, the coleoptile growth was not significantly different among chromium treatments $\left(F_{6,35}=1.74, p=\right.$ 0.140 for $V$. angularis; $F_{6,35}=2.64, p=0.052$ for Lathyrus odoratus; $F_{6,35}=1.44, p=0.228$ for Dumasia villosa). Compared with the control and shorter concentration chromium treatments ( 0.1 and $0.2 \mathrm{mM})$, higher concentration chromium treatments (1.6 and $3.2 \mathrm{mM}$ ) significantly inhabited coleoptile growth for Glycine max, Vigna ratiata and Lablab purpureus. Lablab purpureus performed shorter coleoptile growth at all chromium treatments $(p<0.001)$. Comparing with control, for Glycine max, $0.1 \mathrm{mM}$ chromium treatment significantly promoted the coleoptile growth $(p<0.001), 0.2 \mathrm{mM}$ and $0.4 \mathrm{mM}$ 
Chromium on germination and growth of pulses

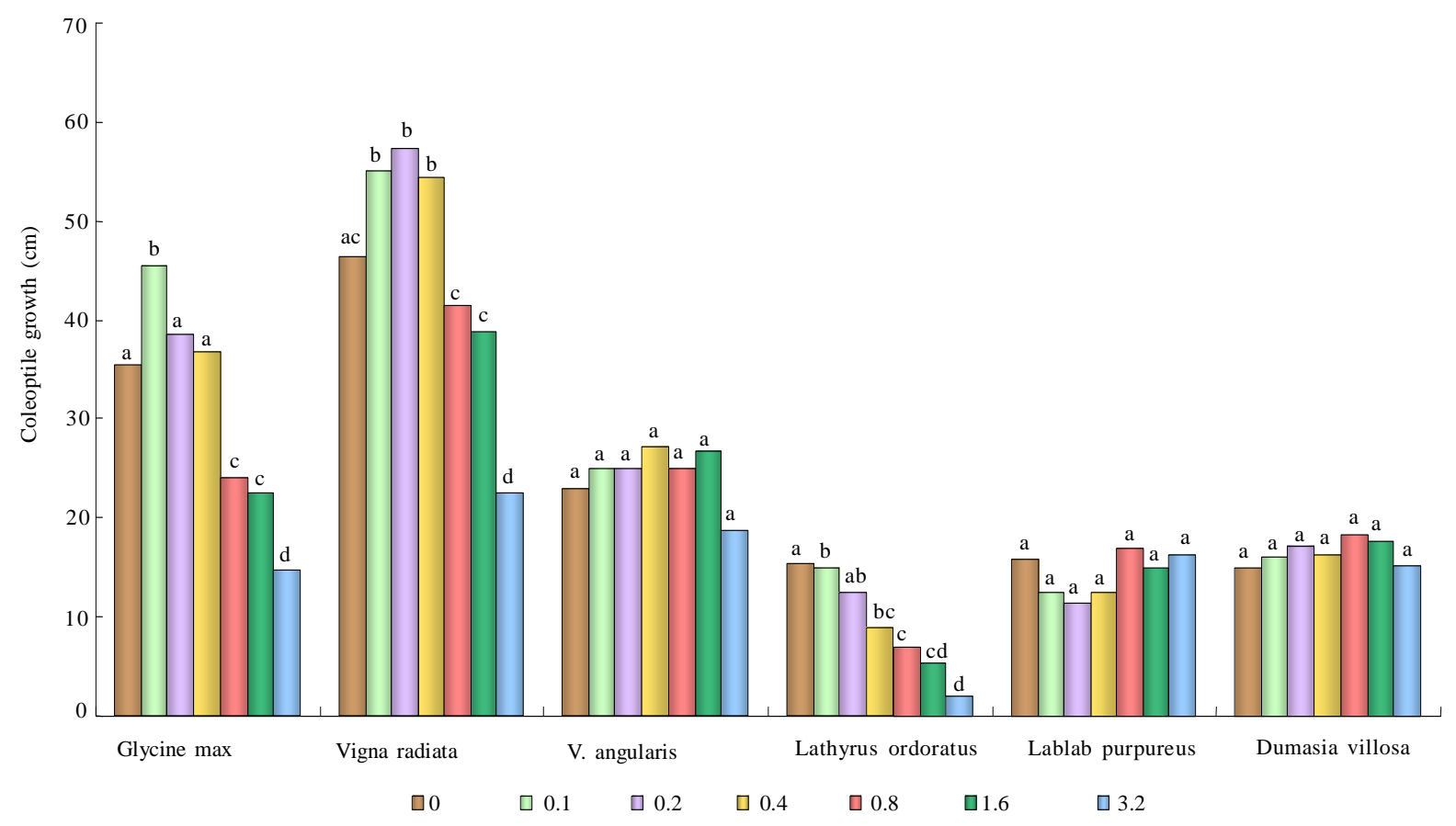

Fig. 2: Coleoptile growth of six species under seven different chromium pollution treatments. Values with the same superscript letters are not significantly different among treatments at $\mathrm{p}<0.01$ according to Duncan's multiple comparison tests

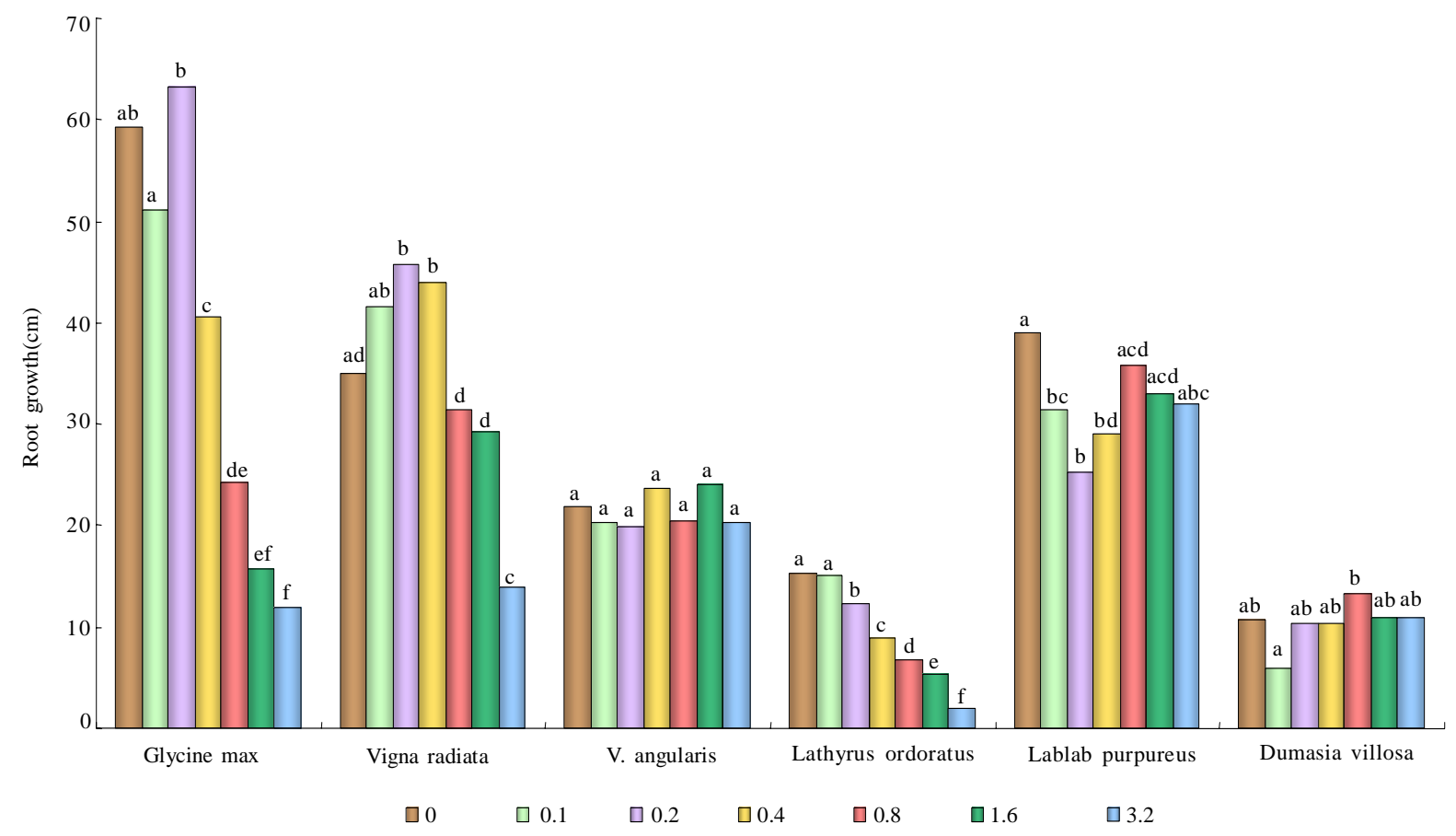

Fig. 3: Root elongation of six species under seven different chromium pollution treatments. Values with the same superscript letters are not significantly different among treatments at $\mathrm{p}<0.01$ according to Duncan's multiple comparison tests 
Int. J. Environ. Sci. Tech., 6 (4), 571-578, Autumn 2009

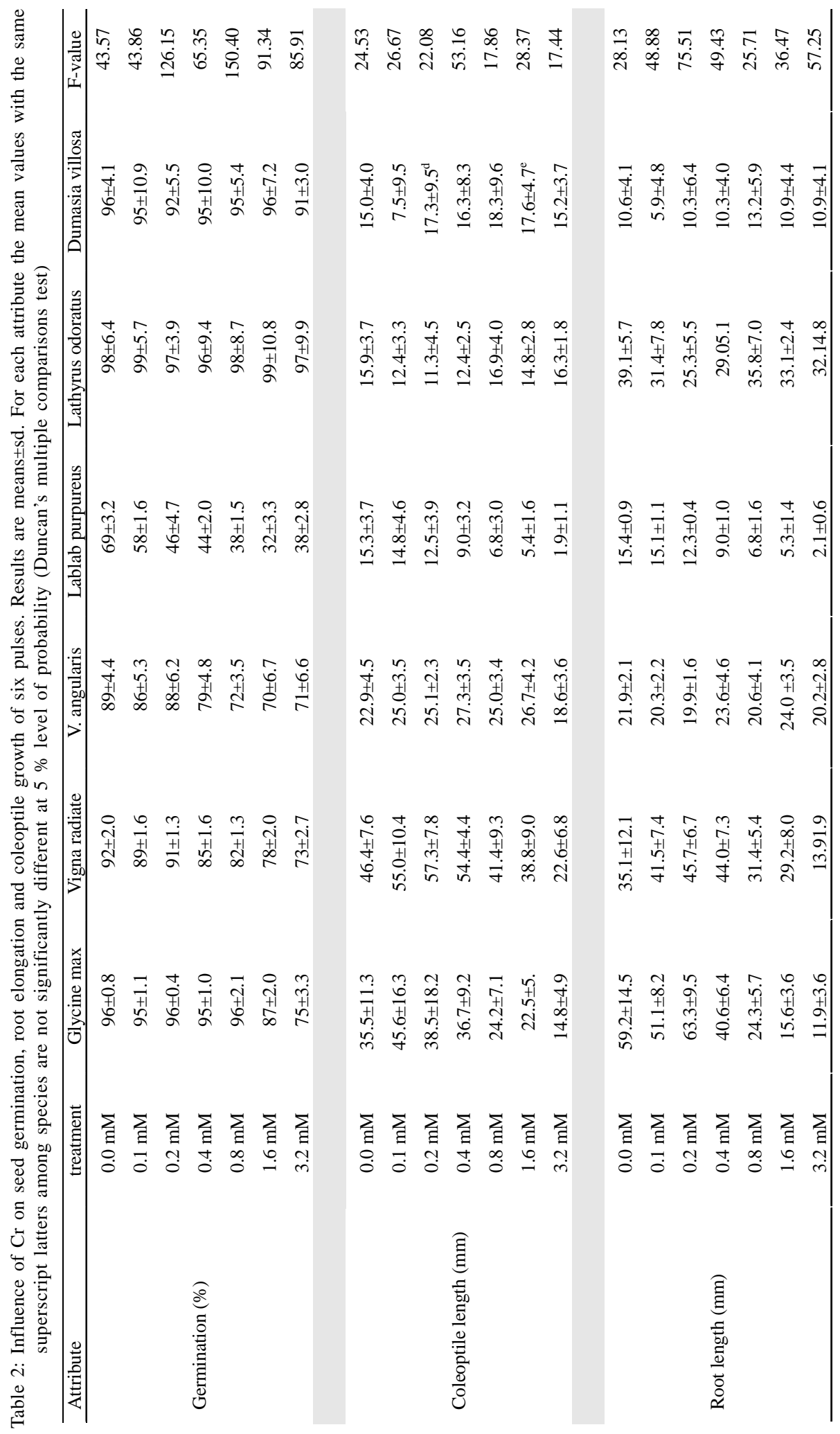


chromium treatments had no significant influence on coleoptile growth and for Vigna ratiata, lower chromium treatments $(0.1,0.2$ and $0.4 \mathrm{mM})$ significantly promoted the coleoptile growth $(p<0.001)$ (Fig. 2).

The coleoptile growth was significantly different among species at six kinds of chromium treatments and one control $(p<0.001)$ (Table 2$)$. The coleoptile growth of Lablab purpureus decreased with addition of chromium concentration (Fig. 2). At control treatment, Glycine max and Vigna ratiat did not performed significant difference in the coleoptile growth, but their coleoptile growth was significantly higher than other 4 species $(p<0.001)$. At higher chromium treatments $(0.4,0.8,1.6$ and $3.2 \mathrm{mM})$, Glycine max and Vigna ratiat performed significant difference $(p<0.001)$ and their coleoptile growth was both significantly higher than other 4 species $(p<0.001)$ and the coleoptile growth of Lablab purpureus was significantly shorter than other 5 species $(p<0.001)$. At 1.6 and $3.2 \mathrm{mM}$ chromium treatment, the coleoptile growth of Vigna ratiat was significantly higher than 5 species and Lablab purpureus was significantly shorter than other 5 species $(p<0.001)$ (Table 2$)$. There was a significant negative correlation between the mean coleoptile length and chromium concentration for three species (Glycine max: $y=38.58-0.89 x, r^{2}=0.79, F_{1,5}=18.26$, $p=0.0079 ;$ Vigna ratiata: $y=53.93-0.92 x, r^{2}=0.85$, $F_{1,5}=29.28, p=0.0029$; Lablab purpureus: $y=12.94-$ $0.90 x, r^{2}=0.81, F_{1,5}=21.06, p=0.0059$ ).

\section{Root elongation under chromium stress}

A two-way ANOVA showed that root elongation was significantly affected by different species $\left(F_{5}=2.0134, P=0.0074\right)$ and chromium treatment $\left(F_{6}=2.2589, P=0.0281\right)$, but not by the interaction between species and chromium treatment (Table 1). The root length was significantly different among chromium treatments in five pulse species (one-way ANOVA: $F_{6,35}=39.47, p<0.001$ for Glycine max; $F_{6,35}=12.81, p<0.001$ for Vigna ratiata; $F_{6,35}=3.78$, $p=0.005$ for Dumasia villosa; $F_{6,35}=136.51, p<0.001$ for Lablab purpureus; $F_{6,35} \stackrel{2,35}{=} 3.69, p=0.006$ for Lathyrus odoratus). For $V$. angularis, the root elongation was not significantly different among chromium treatments. Compared with the control and shorter concentration treatments $(0.1,0.2$ and $0.4 \mathrm{mM}$ ), highest concentration chromium treatments $(0.8,1.6$ and $3.2 \mathrm{mM})$ significantly inhabited root elongation for Glycine max $(p<0.001)$. For Vigna ratiata, the root length dramatically decreased at $3.2 \mathrm{mM}$ chromium treatment and was significantly shorter than other species $(p<0.001)$. The root elongation of Lablab purpureus performed decline with increase of chromium concentration. The root elongation of Dumasia villosa was not effected by chromium treatments comparing with the control (Fig. 3).

There was significantly difference of root elongation among species $(p<0.001)$ at six kinds of chromium treatments and one control (Table 2). At control treatment and lower chromium concentration treatments $(0.1$ and $0.2 \mathrm{mM})$, the root length of Glycine max was significantly longer than other 5 species $(p<0.001)$; the root lengths of Lablab purpureus and Dumasia villosa were significantly shorter than other 4 species $(p<0.001)$; the root lengths of Vigna ratiata was significantly shorter than Glycine max and longer than other 4 species $(p<0.001)$. At higher chromium concentration treatments (1.6 and $3.2 \mathrm{mM}$ ), there was not significant difference between Glycine max and Dumasia villosa. The root length of Lablab purpureus was significantly shorter than other 5 species (Table 2). There was a significant negative correlation between the mean coleoptile length and chromium concentration for three species (Glycine max: $y=$ 51.85-15.41x, $r^{2}=0.85, F_{1,5}=12.69, p=0.0162$; Vigna ratiata: $y=42.25-8.71 x, r^{2}=0.83, F_{1,5}=24.92, p=$ 0.0041; Lablab purpureus: $y=12.96-3.93 x, r^{2}=0.80$, $F_{1,5}=19.42, p=0.0070$ ).

Chromium is very important for the normal growth of plants, although stimulating effects to the additions of $\mathrm{Cr}$ on plant growth have been observed by several researchers (Lintschinger et al., 1997), but excessive amount can leads to toxicity. The $\mathrm{Cr}^{2+}$ showed very strong inhibits effect to germination, root and coleoptile growth of the test species, especially at high chromium concentrations and the root and shoot growth were much more sensitive than the germination by this study. High levels of $\mathrm{Cr}^{2+}$ supply can inhibit seed germination and subsequent seedling growth (Zayed and Terry, 2003). In another study, $\mathrm{Cr}$ (VI) concentrations up to $2 \mathrm{mM}$ supplied as $\mathrm{K}_{2} \mathrm{Cr}_{2} \mathrm{O}_{7}$ did not affect germination of pea seeds significantly, this was similar results for Vigna angularis and Lathyrus ordoratus by this 
study. However, growth of root and shoot was suppressed at chromium concentrations of $0.5 \mathrm{mM}$. The seed yield was reduced by $75-80 \%$ and even at $0.1 \mathrm{mM}$ Cr seed yield was reduced by about $70 \% \mathrm{At}$ Cr(VI) concentration of $0.2 \mathrm{mM}$ (Bishnoi et al., 1993). Munzuroglu and Geckil (2002) demonstrate that inhibition of root elongation is considered to be the first evident effect metal toxicity in plants, may be it's because of the seed coat is able to reduce the amount of $\mathrm{Cr}^{2+}$ entering the seed, but after the seed germination, chromium is considered strongly toxic because chromium compound in the soil are more or less insoluble as the metal ions are tightly bound to humus and clay particles. Shoot and root after germination have no barrier to protect. Some other studies have the same conclusion (Rout et al., 2000).

\section{CONCLUSION}

This study concluded that seed germination of all the test species were not so sensitive like root and coleoptile elongation to $\mathrm{Cr}^{2+}$, root and coleoptile growth of the test species were more accurate to measure the toxic of $\mathrm{Cr}^{2+}$ pollutions and different species show different levels of tolerance to $\mathrm{Cr}^{2+}$. Lablab purpureus and Glycine max are the most sensitive to $\mathrm{Cr}^{2+}$. By contrast, Lathyrus odoratus and Dumasia villosa are the most resist species.

\section{REFERENCES}

Babel, S.; Opiso, E. M., (2007). Removal of Cr from synthetic wastewater by sorption into volcanic ash soil. Int. J. Environ. Sci. Tech., 4 (1), 99-107 (9 pages).

Bishnoi, N. R.; Dua, A.; Gupta, V. K.; Sawhney, S. K., (1993). Effect of chromium on seed germination, seedling growth and yield of peas. Agr. Ecosyst. Environ., 47 (1), 47-57 (11 pages).

Citterio, S.; Santagostino, A.; Fumagalli, P.; Prato, N.; Ranalli, P.; Sgorbati, S., (2003). Heavy metal tolerance and accumulation of $\mathrm{Cd}, \mathrm{Cr}$ and $\mathrm{Ni}$ by Cannabis sativa L. Plant Soil. 256 (2), 243-252 (10 pages).

Du, Y.; He, J. H.; Chen, J. J.; Wei, X. G.; Yang, X. Q.; Wang, S. Y.; He, W. B., (2003). Effects of heavy metals of Pb, Cd and $\mathrm{Cr}$ on the growth of vegetables and their uptake. Acta Horticulturae Sin., 30 (1), 51-55 (5 pages) (in Chinese).

Dube, B. K.; Tewari, K.; Chatterjee, J.; Chatterjee, C., (2003). Excess chromium alters uptake and translocation of certain nutrients in citrullus. Chemosphere, 53 (9), 1147-1153 (7 pages).

Faisal, M.; Hasnain, S., (2005). Chromate resistant Bacillus cereus augments sunflower growth by reducing toxicity Cr (VI). J. Plant Biol., 48 (2), 187-194 (8 pages).

Gardea-Torresdey, J. L.; Rosa, G.; Peralta-Videa, J. R.; Montes, M.; Cruz-Jimenez, G.; Cano-Aguilera, I., (2005). Differential uptake and transport of trivalent and hexavalent chromium by tumbleweed (Salsola kali). Arch. Environ. Contamin. Toxicol., 22 (1), 19-25 (7 pages).

Gbaruko, B. C.; Friday, O. U., (2007). Bioaccumulation of heavy metals in some fauna and flora. Int. J. Environ. Sci. Tech., 4 (2), 197-202 (6 pages).

Hasnain, S.; Sabri, A. N., (1997). Growth stimulation of Triticum Aestivum seedlings under Cr-stresses by nonrhizospheric pseudomonad strains. Environ. Pollut., 97 (3), 265-273 (9 pages).

Jain, R.; Srivastava, S.; Madan, V. K.; Jain, R., (2000). Influence of chromium on growth and cell division of sugarcane. Indian J. Plant Physiol., 5 (3), 228-231 (4 pages).

Jamal, S. N.; Iqbal, M. Z.; Athar, M., (2006). Phytotoxic effect of aluminum and chromium on the germination and early growth of wheat (Triticum aestivtum) varieties Anmol and Kiran. Int. J. Environ. Sci. Tech., 3 (4), 411-416 (6 pages).

Kar, D.; Sur, P.; Mandal, S. K.; Saha, T.; Kole, R. K., (2008). Assessment of heavy metal pollution in surfacewater. Int. J. Environ. Sci. Tech., 5 (1), 119-124 (6 pages).

Karbassi, A. R.; Nouri, J.; Mehrdadi, N., Ayaz, G. O., (2008). Flocculation of heavy metals during mixing of freshwater with Caspian Sea water. Environ. Geo., 53 (8), 1811-1816 (6 pages).

Li, Y.; Yang, X. K., (2006). The effects of single Cr and complex pollutants and La on the growth of rice seedlings. J. of Guizhou Normal University (Natural Sciences), 24 (1), 39-42 (4 pages) (in Chinese).

Lintschinger, J.; Fuchs, N.; Moser, H.; Jager, R.; Hlebeina, T.; Markolin, G.; Gossler, W., (1997). Uptake of various trace elements during germination of wheat, buckwheat and quinoa. Plant Food Hum. Nutr., 50 (3), 223-237 (15 pages).

Manjappa, S.; Sunitha, D. R.; Puttaiah, E. T., (2002). Studies on the effect of chromium on seed germination of few vegetable crops. Ecol. Environ. Conserv., 8 (2), 195-197 (3 pages).

Munzuroglu, O.; Geckil, H., (2002). Effects of metals on seed germination, root elongation, and coleoptile and hypocotyl growth in Triticum aestivum and Cucumis sativus. Arch. Environ. Contamin. Toxicol., 43 (2), 203213 (11 pages).

Nath, K.; Saini, S.; Sharma, Y. K., (2005). Chromium in tannery industry effluent and its effect on plant metabolism and growth. J. Environ. Biol., 26 (2), 197 204 (8 pages).

Ogundiran, O. O.; Afolabi, T. A., (2008). Assessment of the physicochemical parameters and heavy metals' toxicity of leachates from municipal solid waste open dumpsite. Int. J. Environ. Sci. Tech., 5 (2), 243-250 (8 pages).

Parmar, N. G.; Vithalani, S. D.; Chanda, S. V., (2002). Alteration in growth and peroxidase activity by heavy metals in Phaseolus seedlings. Acta Physiolog. Plant., 24 (1), 89-95 (7 pages).

Peralta, J. R.; Gardea-Torresdey, J. L.; Tiemann, K. J.; Gomez, E.; Arteaga, S.; Rascon, E.; Parsons, J. G., (2001). Uptake and effects of five heavy metals on seed germination and plant growth in alfalfa (Medicago sativa L.). Bull. Environ. Contamin. Toxicol., 66 (6), 727-734 (8 pages).

Ren, A. Z.; Gao, Y. B., (2000). Effects of single and combinative pollutions of lead, cadmium and chromium 
on the germination of Brassica chinensis L. Chinese J. Ecol., 19 (1), 19-22 (4 pages) (in Chinese).

Rout, G. R.; Sanghamitra, S.; Das, P., (2000). Effects of chromium and nickel on germination and growth in tolerant and non-tolerant populations of Echinochloa colona (L.) link. Chemosphere, 40 (8), 855-859 (5 pages).

Scoccianti, V.; Crinelli, R.; Tirillini, B.; Mancinelli, V.; Speranza, A., (2006). Uptake and toxicity of Cr (III) in celery seedlings. Chemosphere, 64 (10), 1695-1703 (9 pages).

Shrestha, R.; Fischer, R.; Sillanpää, M., (2007). Investigations on different positions of electrodes and their effects on the distribution of $\mathrm{Cr}$ at the water sediment interface. Int. J. Environ. Sci. Tech., 4 (4), 413-420 (8 pages).

Srivastava, S.; Thakur, I. S., (2006). Evaluation of bioremediation and detoxification potentiality of Aspergillus niger for removal of hexavalent chromium in soil microcosm. Soil Biol. Biochem., 38 (7), 1904-1911 (8 pages).

Venkateswaran, P.; Vellaichamy, S.; Palanivelu, K., (2007). Speciation of heavy metals in electroplating industry sludge and wastewater residue using inductively coupled plasma. Int. J. Environ. Sci. Tech., 4 (4), 497-504 (8 pages).

Wong, J. W. C.; Lai, K. M.; Su, D. S.; Fang, M., (2001). Availability of heavy metals for Brassica chinensis grown in an acidic loamy soil amended with a domestic and an industrial sewage sludge. Water Air Soil Pollut., 128 (3-4), 339-353 (15 pages).

Zayed, A. M.; Terry, M., (2003). Chromium in the environment: Factors affecting biological remediation. Plant and Soil., 249 (1), 139-156 (18 pages).

Zeid, I. M., (2001). Responses of Phaseolus vulgaris to chromium and cobalt treatments. Biologia Plantarum., 44 (1), 111-115 (5 pages).

Zhou, X. Q.; Li, Y. H., (2003). Ecological effects of $\mathrm{Ca}^{2+}$ on the seed germination of Casuarina equisetifolia under chromic stress. Chinese J. Ecol., 22 (4), 37-41 (5 pages) (in Chinese).

Zhou, X. Q.; Li, Y. H., (2004). The physiological and ecological responses of the seed germination of Casuarina equisetifolia to chromic stress. Chinese J. Eco-Agri., 12 (1), 53-55 (3 pages).

\section{AUTHOR (S) BIOSKETCHES}

Jun, R., Ph.D., Professor, School of Environmental and Municipal Engineering and Institute of Environmental Ecology, Lanzhou Jiaotong University, Lanzhou and a postdoctoral researcher in College of Life Science, Lanzhou University, Lanzhou 730070, Gansu, P. R. China. Email: renjun@mail.lzjtu.cn

Ling, T., Ph.D., Professor, School of Environmental and Municipal Engineering and Institute of Environmental Ecology, Lanzhou Jiaotong University, Lanzhou 730070, Gansu, P. R. China. Email: taoling@mail.lzjtu.cn

Guanghua, Z., M.Sc. student, School of Environmental and Municipal Engineering and Institute of Environmental Ecology, Lanzhou Jiaotong University, Lanzhou 730070, Gansu, P. R. China. Email: zhuguanghua@mail.lzjtu.cn 